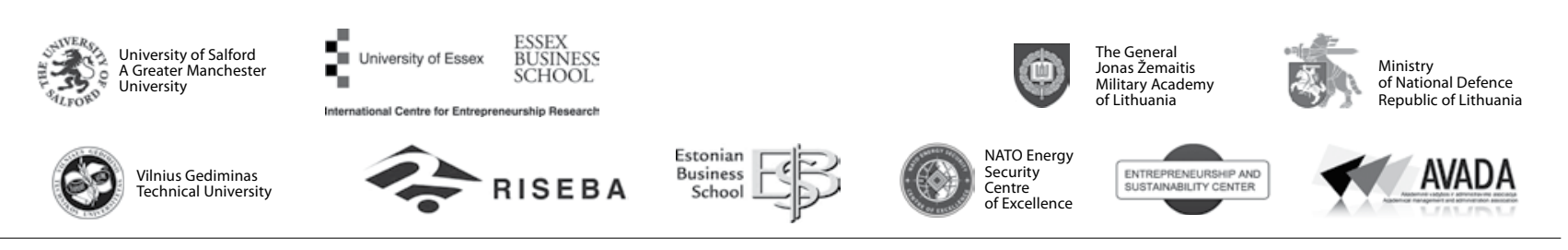

\author{
JOURNAL OF SECURITY AND SUSTAINABILITY ISSUES \\ ISSN 2029-7017 print/ISSN 2029-7025 online \\ 2017 June Volume 6 Number 4 \\ http://dx.doi.org/10.9770/jssi.2017.6.4(1)
}

\title{
RENEWABLE ENERGY POTENTIAL IN THE AUTOMOTIVE SECTOR: CZECH REGIONAL CASE STUDY
}

\author{
Viera Pechancová \\ Faculty of Management and Economics, Tomas Bata University in Zlin, \\ 5139 Mostni Str., Zlin, 760 01, Czech Republic \\ E-mail:pechancova@fame.utb.cz
}

Received 11 February 2017; accepted 17 May 2017

\begin{abstract}
Bearing in mind the instant innovations in renewables and the pressures to adopt ecological behaviors, companies are pushed to make changes in the energy field as well. Especially companies in the automotive sector have begun to implement sustainable production practices. The Czech Republic is not an exception, suggesting that sustainable actions have begun to be more significant at the local level as well. This article addresses the state of the art of using sustainable energy actions, concentrating on the renewable energy in the automotive supplier network within a selected region in the Czech Republic. Analyzing a broad context of renewable energy utilization at the regional level, the researched company sample shows that it is not yet a common practice. The results confirm that renewable energy sourcing needs to find its economic viability or justification in environmental legislation. Only then it can further spread along the automotive supply chain.
\end{abstract}

Keywords: automotive supply chain, environmental impact, renewable energy sources, sustainable production

Reference to this paper should be made as follows: Pechancová, V. 2017. Renewable energy potential in the automotive sector: Czech regional case study, Journal of Security and Sustainability Issues 6(4): 537-545. http://doi.org/10.9770/jssi.2017.6.4(1)

JEL Codes: L6

\section{Introduction}

Global growth trends in vehicle sales make the automotive sector powerful worldwide, reflected in direct and indirect employment and industrial output share (ACEA, 2016). In the Czech Republic, up to $25 \%$ of the country's industrial production and 7,4\% of GDP is covered by the automotive industry (Kozelský and Novák, 2015), (Autosap, 2014). It belongs thus to the most important industrial sectors at the national as well as regional level.

Social changes such as urbanization, sharing and circular economy and sustainability concepts (Banaite, Tamošiūnienė 2016; Strielkowski et al. 2016; Tvaronavičienė 2016; Ahmed et al. 2017) all influence the automotive industry. The transformation of the automobile industry is mirrored in the visionary statement by General Motors's CEO, who said in 2016, "I believe the auto industry will change more in the next 5 - 10 years than it has in the last 50." (Barra, 2016). More or less discreet signs show that the automotive industry is undergoing a second revolution both in car production and in use. On one hand, it is connected to cities' development, their growing needs, and the cost increase of fossil fuel exploitation (Freyssenet, 2011). On the other hand, the revolution is based on connectivity and changing customer attitudes.

Environmental focus is a clear trend in the automotive industry. According to (Kannegiesser et al., 2014), the 
transportation sector is among the top sources of greenhouse gas (GHG) emissions. More specifically, significant GHG emissions are produced along the production lifecycle, beginning with raw material exploration to the vehicle end-of-use. As a consequence, automotive companies are forced to develop not only smarter and safer cars, but also cleaner. Companies are pressed to initiate green practices, such as environmental management systems, a green balanced scorecard and green supply chain management. Evidence shows that European vehicle manufacturers have continuously reduced the environmental impact of vehicle production (ACEA, 2016).

Manufacturing of automotive parts is a complex process and belongs to the one of the most energy intensive sectors with high energy consumption. Energy is included in many processes in vehicle production, directly or indirectly. The press line, body shell work, material handling equipment, paint finishing system, casting, assembly, inspection and testing all require energy input. Additionally, energy is employed in space heating, steam applications and in the curing ovens of the painting lines (Pardo Martínez, 2011).

Although cars have been equipped to be cleaner, the production complexity has increased affecting also the related energy demand. The tendency of cleaner car production goes hand in hand with technological development. Owing to an energy consumption increase together with the combustion of fossil fuels and volatile conventional energy prices, energy efficiency programs ranging from the thermal insulation of buildings to modern energy supply systems proliferate. Improvement in the energy efficiency of production has resulted in an overall energy consumption decrease of $12,4 \%$ over the last decade.

Renewable energy sources (RES) are important part of GHG emission reduction, affecting the climate positively. RES accounted for $24 \%$ of electricity generation globally in 2014. More specifically, cumulative renewable electricity installed capacity grew by $8 \%$ in 2014 worldwide (from 1,579 GW to 1,712 GW) (2014 Renewable Energy Data Book, 2015). On the other hand, 13,5\% of the world energy consumption was covered by renewable energy (including biomass). Nevertheless, it is only about $4,5 \%$ when excluding ecologically inconvenient firewood in developing countries (Müller-Steinhagen and Nitsch, 2005).

From the consumption as well as the production point of view, RES are finding their place in the automotive industry. As the automotive companies are willing to develop environmentally-friendly vehicles and introduce sustainable production processes, there is further potential space for RES. To illustrate, innovative automotive companies in Germany are investing in sustainable energy projects as part of their company strategy aligning with "Energiewende" politics.

To sum up, the background for this study was motivated especially by recent clean energy projects and continuous innovations in RES technologies. These sustainability initiatives result in the optimization of energy consumption and a decreased impact on the environment. This article explores the current utilization and future potential of RES in selected automotive supply chain companies in the Czech Republic. The study addresses the highly up-to-date connection between renewables and the automotive industry from the production perspective. A case study approach was chosen to analyze RES consumption and its potential implementation. The background associations to energy and environmental management systems is presented and future trends are outlined.

\section{Literature review}

The sustainability concept began to be used in connection with ecological and economic systems in 1970s. Later, it was applied in many areas, including the vehicle manufacturing industry. The basic sustainability concept of the triple bottom line (3BL) introduced by (Elkington, 1997), combines three dimensions of sustainability: economic, social and environmental. This holistic approach measures their impact on profit, people and the planet. Aligned with Porter strategic differentiation, green business solutions contribute to potential competitive advantage.

Environmental responsibility in form of environmentally friendly and more efficient processes enables thus potential differentiation for businesses. The product and process innovations allow for additional benefits in- 
cluding cost savings. From this point of view, the environmental responsibility should be seen as „economic and competitive opportunity, not as an annoying cost or inevitable threat." (Porter and van der Linde, 1995).

Based on the literature sources, there is a close association of energy with environmental considerations in regard of sustainability. The most widely applied sustainability reporting guidelines (the Global Reporting Initiative) classify energy as an environmental aspect. As automotive supply chains are affected by energy prices and GHG emissions constrains, they increasingly implement reducing strategies and create thus solutions through the overall manufacturing process to reduce waste in energy consumption. The authors (Golinska and Kosacka, 2014) present main trends in the energy management in the automotive sector: renewable energy, high-efficiency lighting systems, stand-by systems for equipment, thermal isolation and automated control systems.

As the study concentrates on RES, a convenient definition by the Texas Renewable Energy Industry Alliance (TREIA) needs to be mentioned at this phase: Renewable energy is a resource that is regenerated naturally and originated either directly from the sun (geothermal, photoelectric and photochemical), or indirectly from the sun (hydropower, wind, and photosynthetic energy stored in biomass - organic plant and waste material, landfill gas) (Shin et al., 2016). Generally, RES are seen as more expensive than fossil fuels (Goldemberg, 2007). However, some sorts of clean energy sources are not consistently available, because of weather conditions and climate factors. On the other hand, RES use reduces the environmental impact of production processes and decrease their ecological footprints. Therefore, specific governmental incentives encourage firms in RES adoption. Some authors (Andrade and Puppim De Oliveira, 2015) advocate increasing corporate investment in developing and utilizing RES resources. Simultaneously, the global climate and energy governance have been supporting the effective RES implementation.

Diversification of the energy portfolio mix contributes to the energy security and affects positively vulnerability. In this context, renewable energy sources seem to be affordable means of relief from external energy dependency even though distortions of energy markets might take place (Bilan et al., 2017). As mentioned by (Streimikiene et al., 2016), the renewable energy proportion is relevant indicator for sustainable energy development. Based on Eurostat database the Czech Republic with RES proportion 13,4\% has been lagging behind some other European countries (for example Lithuania with 23,9\% in 2014).

It is important to mention that the overall political, legal and social framework sets the rules for the sustainable energy development. Relevant legal framework in the automotive sector includes EU regulations transferred into national law such as:

- End-Life-Vehicles (ELV directive 2000/53/EC) to prevent waste

- The Directive of type approval of vehicles for reusability, recyclability and recoverability (RRR 2005/64/EC)

- The Directive for the Promotion of Energy from Renewable Sources (Directive 2009/28/EC), which set mandatory national targets (20\% RES proportion by the year 2020$)$.

At the organizational level, the International Standards Organization's ISO 9001 covers overall process of continual improvement and effective business operations. The ISO 14000 standards deal with environmental management providing companies with a framework for evaluating and minimizing the environmental impact of their business operations. This type of certification might be seen as a criterion for companies that have implemented environmental management systems (Mishra and Napier, 2015). The certification of the energy management system ISO 50001 brings together energy efficiency and financial impacts. At the same time it tackles environmental problems with greenhouse gas emissions.

When adopting sustainable measures, comprehensive life cycle approach has been preferred in the automotive industry. Four stages of car life cycle are important from the environmental point of view:

- Design,

- Manufacturing and logistics,

- Utilization

- and end of life (Parkinson and Thompson, 2003)

In each of these stages, energy consumption optimization is possible. Design for sustainability as a theoretical 
background is based on the design-for-X (DfX) principles. This approach implements renewable sources of energy as an element of the design for resource utilization and economy. A comprehensive overview of design for sustainability in automotive is provided by (Mayyas et al., 2012). RES belong to the core trends in innovative product design and sustainable manufacturing processes (Jawahir et al., 2007).

A wide range of studies analyze the sustainability issues from different perspectives. Key sustainable practices from the manufacturing perspective in the Chinese auto industry were examined by (Wang et al., 2015). Another study by (Drohomeretski et al., 2015) reviewed literature sources to identify sustainability practices and performance measures in the automotive sector. Some mostly observed environmental practices were ecodesign $(17,9 \%$ of all examined studies), the use of cleaner fuels $(14,9 \%)$, waste reduction $(13,4 \%)$ and material reuse $(11,9 \%)$. Additionally, improved production procedures and internal quality system certification were observed as well. Analyzing environmental aspects and impacts of the automotive industry, authors (Breno Nunes and David Bennett, 2010) identified green activities in production, namely building construction, operations and manufacturing processes.

Some authors proceed further, advocating the positive relationship between corporate sustainability and firm financial performance. A meta-analysis of the corporate environmental performance and corporate financial performance relationship by (Dixon-fowler et al., 2013) supported that it "pays to be green." Reference (Shin et al., 2016) shows specific association between RES utilization and firm performance, confirming superior financial performance of RES utilizing companies compared to their industry competitors. On the contrary, there are empirical studies showing mixed results not fully supporting environmental management effect on the financial performance. In case of the market reaction to announcements of environmental performance, certain types of announcements were valued even negatively (Jacobs et al., 2010). Some authors come to the conclusion that environmental considerations are influenced by company characteristics: bigger companies with international presence should be more likely environmentally oriented when innovating and tend to be more eco-design oriented. In case of energy reduction no significant differences were found (Peiró-Signes et al., 2014).

The supplier structure plays vital role in the environmental and energy management. Supply chain management can be defined as various types of companies working together in the fields of product, information and finance flow. Most important members in the automotive sector include suppliers, warehouses (tier 1-3), original equipment manufactures (OEMs), distribution centers, dealers and customers. Based on (Sitek and Wikarek, 2014) a representative structure (Fig. 1) of a simple two tier supply chain is presented. Strategic environmental management has been introduced along the whole supply chain, including OEMs and tier suppliers. Some specific energy-related issues, in particular the choice between fossil fuels and RES, need to be considered in the design and operation of modern sustainable supply chains (Ahi et al., 2016). Seen from the supply chain perspective, authors (Bilan et al., 2017) conclude that green supply chain management is driver for the business performance.

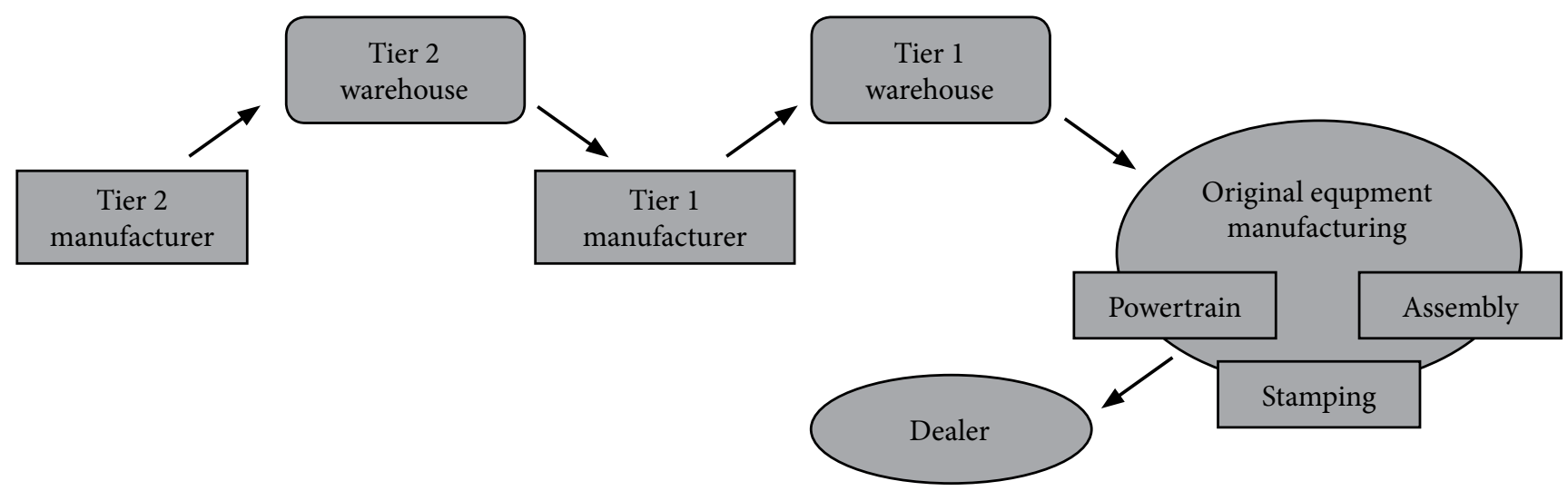

Fig.1. Two tier automotive supply chain 
It can be summarized that renewable energy has been recently one of the essential topics in the field of energy management overreaching to sustainability concepts and sectoral analyses. Contemporary research associated with sustainability and renewable energy use has been emerging. In the study it will be empirically analyzed to what extent is clean energy management important in the plant functioning.

\section{Methodology}

The research question related to the aim of the paper is defined as follows: What is the potential of RES in the selected automotive supply chain companies in the Czech region Moravia?

The applied research method is based on qualitative multiple case study, including explanatory approach. The methods of qualitative research allowed for intentional non-random sampling. Sample of five automotive supplier companies from automotive sector in the Czech region Moravia were chosen. The respondents' positions were directly or indirectly connected to either environmental management or energy management.

Primary as well as secondary data were used in the study. The data were collected via a semi-structured questionnaire. To get well structured information, a combination of open-end and closed-end questions was chosen in the questionnaire. Reverse order Likert scale was applied in one question. The data were collected in the period June 2016 - September 2016. Some additional company data (employee numbers and supplier classification) were obtained via Czechinvest database. The qualitative and quantitative information from the questionnaire was analyzed, including companies' annual reports and web pages. Comparisons to find associations and similarities within qualitative variables were performed.

\section{Findings}

The Czech Republic has a long tradition in manufacturing industry. Particularly the vehicle manufacturing sector represents a key industry belonging to the major employer. As the industry is globally interconnected, the automotive production networks are organized in vertically integrated supplier chains. The Czech automotive firms can be further classified into assemblers, OEM's, and three supplier tiers differing by the complexity of manufactured components and by company characteristics (firm size, corporate power they wield in production networks) (Pavlínek and Ženka, 2015). Large suppliers and OEM's source the Czech market as well as international markets, whereby the main car makers are Škoda Auto, Hyundai Motor Manufacturing Czech and Toyota Peugeot Citroën Automobile.

The company sample for the analysis was chosen so that diverse companies within Moravia region related to the automotive sector are present. The automotive industry in the the Moravia region, being located in the southeastern part of the Czech Republic belongs to the important industrial sectors. The industrial potential including various representatives of automotive supply chain relies in machinery manufacturing, particularly in the area of plastics and rubber (Zlin region) and mechanical engineering companies and representatives of automotive components suppliers (Olomouc region).

Following basic companies' characteristics give an overview of the sample and introduce the companies' background. The company A is a production co-operative founded in Zlin in 1965. The company focuses primarily on the manufacturing and distribution of small electromechanical products, parts for the automotive industry. Being an original equipment manufacturing supplier, second company B is a large producer of off-road tires (agricultural, industrial, motorcycle). Although the history of the company dates back to the 1933, the data in this paper relate to the regional plant built in 2013 with the production of radial agricultural tires. With history back to 1930's, company C operates actively from 1992. The main business area includes production of vehicle tires (automobiles, industrial vehicles, automotive trucks). Company D being the smallest (based on employee numbers) and youngest one - operating since 2012, produces single-purpose machines and is active in vehicle headlights assembly. Finally, company E has diversified production portfolio concentrating on production of plastic parts, laminate tubes and machine tools. 
Together with basic company data, table 1 depicts the most relevant survey findings:

- Company energy manager is appointed in 4 (out of 5) companies

- Company energy strategy is not available in each company ( 3 out of 5)

- Average RES priority is 4 (reverse order Likert scale $1-5$ )

- Generally, RES adoption is expected to have slightly positive financial impact on the companies

- Average renewable energy proportion is $2,5 \%$

\begin{tabular}{|c|c|c|c|c|c|}
\hline & Company A & Company B & Company C & Company D & Company E \\
\hline No. of employees & 254 & 650 & 4400 & 500 & 500 \\
\hline Supplier type & tier 3 & tier 3 & tier 1 & tier 2 & tier 3 \\
\hline Quality certification & $\begin{array}{c}\text { ISO } 14001, \\
\text { ISO } 9001\end{array}$ & $\begin{array}{l}\text { ISO } 14001, \\
\text { ISO } 50001\end{array}$ & $\begin{array}{l}\text { ISO 14001, } \\
\text { ISO 50001 }\end{array}$ & ISO14001 & $\begin{array}{c}\text { ISO 14001 ISO } 9001 \\
\text { ISO/TS } 16949 \\
\end{array}$ \\
\hline Energy strategy & no & yes & yes & no & yes \\
\hline Energy manager & yes & yes & yes & no & yes \\
\hline RES priority $^{a}$ & 5 & 5 & 4 & 3 & 3 \\
\hline Expected financial impact & negative & $\begin{array}{c}\text { Pay-back period } \\
\text { limitation }\end{array}$ & negligible positive & positive & positive \\
\hline
\end{tabular}

Fig. 2. RE share and company size

Scaling the priorities in RES investments only confirms current status. Companies with zero RES utilization, report lowest priority in the RES investments. Additionally, negative financial impact from the investment is expected (in one case). To be more specific, pay-back period measure (PBP) being more than three years seems to be a hurdle rate. Three other companies with RES experience see at least negligibly positive effect on the financial performance.

It was also observed that tangible financial benefits together with environmental legislation are the main driver for the current RES utilization. Also flexibility of decision-making in smaller businesses might play a role. On the other hand, fluctuations in solar and wind energy supply caused by weather conditions might be additional burden for baseload demand.

Future trends and developments regarding the RES in the examined automotive businesses concentrate on saving measures and decreasing environmental impacts. The anticipated projects encompass own substation within the plant or solar thermal collector systems for water heating and auxiliary space heating. Other priorities within the broad field of environmental care such as savings related to water consumption or industrial waste elimination were mentioned.

Many of the companies have invested in energy saving initiatives to reduce energy consumption. As a next step, when the saving potential of fossil-fuel-based technologies is exhausted, the RES implementation would make sense. Energy cost savings compared to the initial investment in renewable equipment seem to be the toughest burden to overcome. The research shows challenging task to overcome internal and external barriers within the companies. As the main consideration is related to the pay-back period measure, potential incentives for RES implementation include initial governmental support. Some other potential drivers encompass legal requirements and standards and requirements by stakeholders. Along with financial reasoning, the benefits would include increased competitive position and reduced environmental impact.

\section{Conclusions}

Based on the study findings and aligned with the literature it can be concluded that RES as a sustainable practice are finding their way to the automotive sector companies. Signs of increased interest can be found at the regional level. Three out of five researched businesses already utilize RES, all of them confirming positive financial impact as well. 
It needs to be mentioned that the long-term view of alternative sources of energy is automatically compared to other prospective company projects in an organization (marketing, production capacity expansion, product quality improvement and many others). On the other hand, legislative requirements, potential cost reduction, company image and growing public pressure push forward the motivation to invest in sustainable projects. Multiple case study survey confirmed that energy saving measures and emission reduction play important role within the complex environmental and energy management field. Confirming the results from the literature sources, the sustainable production design starts to play an important role.

However, pro-environmental and energy behavior in the regional automotive assembly industry seems to be still lacking behind current trends in the developed countries. Barriers and drivers for RES adoption need to be further examined. Bottom-up principle in RES adoption needs to be in line with the energy policies. Aligned with some research conclusions (Bilan et al., 2017), healthy energy balance mix of traditional sources and RES should be supported. Municipal projects and community collaboration in sustainable and renewable energy adoption need to be supported as well. Despite obvious barriers such as technological and economic there is a huge potential for behavioral applications and social science contribution.

The limitation of the paper is related to the non-randomness of the sample and sample quantity. Although the study includes representatives from the automotive supply chain varying in the main business, size or legal entity, more companies in the sample would allow for quantitative analysis with more generalizable results.

Possible extension of the research could be an analysis of a representative dataset of automotive companies with application of statistical testing. Also comparison of the renewable energy potential between smaller firms and larger firms, or among the companies within tier groups would bring interesting results. Comparison to the Nordic automotive businesses could indicate sustainable business models for this industry, as Nordic countries utilize high shares of RES within their overall energy consumption. Other related research questions to be answered in the future research include:

- What are the proportions of renewables in the companies along the automotive supply chains?

- What are the effects of instable energy prices on automotive sector performance?

- How are local firms prepared for the new/alternative energy sources?

In conclusion, the market demand for fuel-efficient cars is linked to the sustainable production as well. Along with the development of automobiles running on technologies differing from the internal-combustion engine, the manufacturing and assembly of these cars in facilities powered by alternative energies will evolve. Beginning with major car manufacturers, it is a question of time when the alternative energy sources will spread along the whole supply chain.

\section{Acknowledgment}

The author is thankful for the financial support received from the Czech Science Foundation, grant No. 1625536S: "Methodology of Developing a Predictive Model of Sector and Company Performance in the Macroeconomic Context".

\section{References}

2014 Renewable Energy Data Book, 2015.

ACEA, 2016. The Automobile Industry Pocket Guide 2015/2016.

Ahi, P., Searcy, C., Jaber, M.Y., 2016. Energy-related performance measures employed in sustainable supply chains: A bibliometric analysis, Sustainable Production and Consumption 7: 1-15.

Ahmed, A.; McGough, D.; Mateo-Garcia, M. 2017. Testing innovative technologies for retrofitting: Coventry University as a living lab, Entrepreneurship and Sustainability Issues 4(3): 257-270. http://dx.doi.org/10.9770/jesi.2017.4.3S(2)

Andrade, J.C.S., Puppim De Oliveira, J.A., 2015. The Role of the Private Sector in Global Climate and Energy Governance, Journal of 
Business Ethics 130: 375-387. http://doi.org/10.1007/s10551-014-2235-3

Autosap, 2014. Autosap.

Banaitè, D.; Tamošiūnienė, R. 2016. Sustainable development: the circular economy indicators' selection model, Journal of Security and Sustainability Issues 6(2) 315-323. DOI: http://dx.doi.org/10.9770/jssi.2016.6.2(10)

Barra, M., 2016. Davos 2016: GM Boss Sees A Revolution In Personal Mobility [WWW Document]. URL http://www.forbes.com/sites/ joannmuller/2016/01/18/davos-2016-gm-boss-sees-a-revolution-in-personal-mobility/\#13df0fb675e3

Bilan, Y., Strielkowski, W., Karbach, R., Mentel, G. 2017. Secure development of country and competitiveness issues: case of Germany's energy security, Journal of Security and Sustainability Issues 6(3): 329-342 http://dx.doi.org/10.9770/jssi.2017.6.3(1)

Breno Nunes, David Bennett, 2010. Green operations initiatives in the automotive industry: An environmental reports analysis and benchmarking study, Benchmarking 17: 396-420. http://doi.org/10.1108/14635771011049362

Dixon-fowler, H.R., Slater, D.J., Johnson, J.L., Ellstrand, A.E., Romi, A.M., 2013. Beyond “Does it Pay to be Green?” A Meta-Analysis of Moderators of the CEP-CFP Relationship, Journal of Business Ethics 112: 353-366 http://doi.org/10.1007/s10551-012-1268-8

Drohomeretski, E., da Costa, S.E.G., de Lima, E.P., Neves, T.R. de O., 2015. The Application of Sustainable Practices and Performance Measures in the Automotive Industry: A Systematic Literature Review, Engineering Management Journal 27: 32-44.

Elkington, J., 1997. Cannibals with forks. The triple bottom line of 21 st century.

Freyssenet, M., 2011. Three possible scenarios for cleaner automobiles, International Journal of Automotive Technology and Management 11: 300-311. http://doi.org/10.1504/IJATM.2011.043163

Goldemberg, J., 2007. Ethanol for a Sustainable Energy Future, Science 315: 808-810.

Golinska, P., Kosacka, M., 2014. Environmental friendly practices in the automotive industry, in: Environmental Issues in Automotive Industry. Springer, pp. 3-22.

Jacobs, B.W., Singhal, V.R., Subramanian, R., 2010. An empirical investigation of environmental performance and the market value of the firm, Journal of Operations Management 28: 430-441. http://doi.org/10.1016/j.jom.2010.01.001

Jawahir, I., Rouch, K., Dillon, O., Holloway, L., Hall, A., 2007. Design for sustainability (DFS): new challenges in developing and implementing a curriculum for next generation design and manufacturing engineers, International Journal of Engineering Education 23: $1053-1064$.

Kannegiesser, M., Günther, H., Gylfason, Ó., 2014. Sustainable development of global supply chains--part 2: investigation of the European automotive industry, Flexible Services and Manufacturing Journal 26: 48-68. http://doi.org/10.1007/s10696-013-9177-4

Kozelský, T., Novák, R., 2015. Automotive Industry: Future Trends.

Mayyas, A., Qattawi, A., Omar, M., Shan, D., 2012. Design for sustainability in automotive industry: A comprehensive review, Renewable and Sustainable Energy Reviews 16: 1845-1862. http://doi.org/10.1016/j.rser.2012.01.012

Mishra, R., Napier, R., 2015. Linking Sustainability to Quality Management and Firm Performance, International Journal of Business and Management 10: 1-10.

Müller-Steinhagen, H., Nitsch, J., 2005. 7th World Congress of Chemical EngineeringThe Contribution of Renewable Energies to a Sustainable Energy Economy, Process Safety and Environmental Protection 83: 285-297. http://doi.org/10.1205/psep.05084

Pardo Martínez, C.I., 2011. Energy efficiency in the automotive industry evidence from Germany and Colombia. Environment, Development and Sustainability 13: 367-383. http://doi.org/10.1007/s10668-010-9266-4

Parkinson, H., Thompson, G., 2003. Analysis and taxonomy of remanufacturing industry practice. Proceedings of the Institution of Mechanical Engineers, Part E: Journal of Process Mechanical Engineering 217: 243-256.

Pavlínek, P., Ženka, J., 2015. Value creation and value capture in the automotive industry: Empirical evidence from Czechia, Environment and Planning http://doi.org/10.1177/0308518X15619934

Peiró-Signes, A., Payá-Martínez, A., de-Miguel-Molina, M., 2014. What is Influencing the Sustainable Attitude of the Automobile Industry?, in: Environmental Issues in Automotive Industry. Springer, pp. 47-63. 
Porter, M.E., van der Linde, C., 1995. Green and Competitive: Ending the Stalemate.

Shin, H., Ellinger, A.E., Nolan, H.H., DeCoster, T.D., Lane, F., 2016. An Assessment of the Association between Renewable Energy Utilization and Firm Financial Performance, Journal of Business Ethics 1-18. http://doi.org/10.1007/s10551-016-3249-9

Sitek, P., Wikarek, J., 2014. Decision Support in Automotive Supply Chain Management: Declarative and Operational Research Approach, in: Golinska, P. (Ed.), Environmental Issues in Automotive Industry. Springer Berlin Heidelberg, Berlin, Heidelberg, pp. 163-184.

Streimikiene, D., Mikalauskiene, A., Mikalauskas, I., 2016. Comparative Assessment of Sustainable Energy Development in the Czech Republic, Lithuania and Slovakia. Journal of Competitiveness 8.

Strielkowski, W. 2016. Entrepreneurship, sustainability, and solar distributed generation, Entrepreneurship and Sustainability Issues 4(1): 9-16. http://dx.doi.org/10.9770/jesi.2016.4.1(1)

Strielkowski, W.; Lisin, E.; Tvaronavičienè, M. 2016. Towards energy security: sustainable development of electrical energy storage, Journal of Security and Sustainability Issues 6(2): 235-244. http://dx.doi.org/10.9770/jssi.2016.6.2(4)

Tvaronavičienè, M. 2016. Entrepreneurship and energy consumption patterns: case of hoseholds in selected countries, Entrepreneurship and Sustainability Issues 4(1): 74-82. http://dx.doi.org/10.9770/jesi.2016.4.1(7)

Wang, Z., Subramanian, N., Gunasekaran, A., Abdulrahman, M.D., Liu, C., 2015. Composite sustainable manufacturing practice and performance framework: Chinese auto-parts suppliers' perspective, International Journal of Production Economics 170, Part A, $219-233$. http://doi.org/10.1016/j.ijpe.2015.09.035

Viera Pechancová is a doctoral student at the Tomas Bata University in Zlin, Czech Republic, specializing in environmental and energy economics with focus on renewable energy. At the same time she has been working as a senior specialist at Innogy, s.r.o. since 2007. Her duties include natural gas volume planning, both short-term and long-term and cash flow analyses and short/long position reporting within natural gas portfolio. Research interests: energy management; regional energy iniciatives; renewable energy sources; sustainability. 